\title{
COMPOSITION OF PLANKTONIC ORGANISMS AND ITS ASSOCIATED PHYSICO-CHEMICAL PARAMETERS IN TWO PONDS AT AFRICAN REGIONAL AQUACULTURE CENTRE (ARAC) ALUU, PORT HARCOURT
}

\author{
G. N. WOKE AND I. P. ALELEYE-WOKOMA \\ (Received 17 March 2009; Revision Accepted 8 June 2010)
}

\begin{abstract}
Composition of plankton communities in two ponds at African Regional Agriculture Centre (ARAC) Aluu, Port Harcourt was undertaken between May and June 2004, to assess the composition, relative abundance and distribution of plankton. The diversity of plankton was poor. Twenty-eight taxa representing four (4) families were recorded for phytoplankton while seventeen taxa representing four families were identified for zooplankton. Chlorophyta and Cladocera were the most dominant classes in phytoplankton and zooplankton in terms of abundance, constitute $13.0 \%$ and $17.1 \%$ respectively. The water quality of the ponds is evident by high temperature $\left(28.8^{\circ} \mathrm{C}\right)$, depth $(57.5 \mathrm{~cm})$, transparency $(42)$, dissolved oxygen $(4.9 \mathrm{mg} / \mathrm{l})$ and low BOD of $(1.4 \mathrm{mg} / \mathrm{l})$. The lower density of organisms could be partly attributed due to heavy rainfall which destabilize the surface water and substrate. Hence, extensive studies of the ponds where aquatic organisms are kept should be carried out to maintain proper utilization of ponds.
\end{abstract}

KEYWORDS: Plankton, composition, communities richness, abundance.

\section{INTRODUCTION}

The plankton community consists of those aquatic organisms having little or no resistance to current, living free, floating and suspended in the open or pelagic waters (Raymond, 1983).

Planktonic plants (phytoplankton) and the planktonic animals (zooplankton) are included in this group, plankton are very important components of the aquatic ecosystem because they are the major primary and secondary links in the trophic chain.

According to Swingle (1985), fertilization results in increased phytoplankton abundance, some plankton genera are more desirable than others.

Southerland (1980) reported that planktonic diatoms show a competitive ability with regards to nutrients which control growth. Chemical factors also affect the abundance and distribution of plankton.

Kasza and Edward (1993), reported that the factors responsible for water blooms are as a result of constant high concentration of nitrogen compound in the water and it's accompanied excessive content of phosphorus.

The zooplankton community derives its members mainly from the phylum arthropoda. Barnes (1980) reported, that the order cladocera contains the most primitive forms and also has small and large species which are consumed by planktivorous fish. Increased production of plankton in ponds is as a result of plankton which results in various fertilizer applications. Several workers have observed that the measurement of phytoplankton biomass or abundance could be seen as indices of potential fish production in ponds (Swingle and Smith, 1999).
The physic-chemical parameters of the environment like temperature, salinity and nutrient, availability affect plankton production. The effects of these conditions have been studied by various workers Menzel and Rhythor 1980 as cited in Raymond (1983). Raymond (1983) stated that plankton species have fairly specific requirements of temperature, light intensity, salinity and nutrients. He also stated that these factors and others affect their distribution and production. Macro nutrients such as iron and zine affect the occurrence of plankton in aquatic media (Raymond, 1983). This study was therefore undertaken to provide some baseline information on the composition of plankton. The study also provides information on the seasonal abundance and distribution of organisms in the study area.

The study was carried out on ponds at the African Regional Aquaculture Centre (ARAC) Aluu, Port Harcourt. The ponds were designated as integrated pond, was $1500 \mathrm{~m}^{2}$ while that the nursery pond was $200 \mathrm{~m}^{2}$. The integrated pond was stocked with tilapia Oreochromis niloticus and the fish fed with supplementary feed of "Branblo" which is a mixture of wheat bran and cow blood. Pig manure at a rate of $30 \mathrm{~kg}$ (ha daily was used for the fertilization). The nursery pond was used for the fingerling production of the cat fish (Clarias garipinus). The pond was fertilized with organic (pig manure) at a rate of $20 \mathrm{~kg}$ (ha daily and in organic fertilizers). The composition of the organic fertilizer was N.P.K $15+15+15$ and urea, at the rate of $75 \mathrm{~kg} / \mathrm{ha}, 50 \mathrm{~kg} / \mathrm{ha}$ and $30 \mathrm{~kg} / \mathrm{ha}$ once per breeding cycle.

\section{MATERIALS AND METHODS}

Plankton samples were collected with plankton

G. N. Woke, Department of Environmental Biology, University of Port Harcourt, P.M.B 5323, Port Harcourt, Nigeria.

I. P. Aleleye-Wokoma, Department of Environmental Biology, University of Port Harcourt, P.M.B 5323, Port Harcourt, Nigeria. 
nets of a mesh size of 55 micro diameters from each pond 22 and 24 . To filter effectively the plankton net was lowered slowly not faster than about 1 - 15 knots. Samples were collected every two week in the afternoon for two months, giving a total of four samples. After towing the collecting bottle was unscrewed and the materials in it emptied in a plastic container and preserved with $10 \%$ formalin to which rose-bengal has been added. The plankton sample was thoroughly mixed and $1 \mathrm{ml}$ of the sample drawn out with a pipette into a Sedgwick raft counting chamber. This was examined under the electrical Nikon biological microscope with magnification of 5000 . Plankton were identified and total number per species counted and recorded. The following identification keys were used, Eze (2001), Hart (1994). Temperature at each pond was recorded using a mercury in glass thermometer. The $\mathrm{pH}$ of the water samples were measured with a Cole - Parmer digital $\mathrm{pH}$ metre with model mettle 430. A meter rule was used in measuring the depth of the pond, transparency were measured with a secchi disc. Biochemical oxygen demand (BOD) and dissolved oxygen (DO) was determined using the 5 days BOD test adapted from APHA (1998).

\section{RESULTS}

Twenty-eight taxa of phytoplankton, representing 4 families and seventeen taxa of zooplankton representing 4 families were recorded from the two ponds. Checklist of the plankton is presented in Table 1 and 2. Physico-chemical parameters of the pond were also presented in Table 3 while the total number of organisms, number of families and relative richness are showed in Table 4 and 5.

Chlorophyta and Cladocera were the most dominant classes in phytoplankton and zooplankton. The class Chlorophyta had the highest number of species (288), followed by Bacillariophyta (245), Euglenophyla (221) and Cyanophyta had (110) for phytoplankton while in zooplankton, the class Cladocera had the highest number of species (400), followed by Copepoda (317), Rotifera (308) and Protozoa (268). The class Chlorophyta had the highest percentage composition of (20.0\%), while Euglenophyta, Bacillariophyta and Cyanophyta had the lowest percentage value of $(17.7 \%),(15.5 \%)$ and $(8.8 \%)$, based on the overall species composition of phytoplankton. In zooplankton, the class protozoa had the percentage composition of $(11.1 \%)$ while Rotifera, Copepoda and Cladocera had the lowest equal percentage composition of $(8.8 \%)$.

Table 1: Phytoplankton collected from the pond at the African Regional Aquaculture Centre (ARAC), Aluu, Port Harcourt

\begin{tabular}{|c|c|}
\hline $\begin{array}{l}\text { Class } \\
\text { Family }\end{array}$ & $\begin{array}{l}\text { Euglenophyta } \\
\text { Euglenophyceae } \\
\text { Trachelonomas similes } \\
\text { Euglena acus } \\
\text { Phacus candulus } \\
\text { Trachelomonas armatta } \\
\text { Trachelomonas viovocina } \\
\text { Phacus longicauda } \\
\text { Pleodorma californike } \\
\text { Euglena sanguinea }\end{array}$ \\
\hline $\begin{array}{l}\text { Class } \\
\text { Family }\end{array}$ & $\begin{array}{l}\text { Chlorophyta } \\
\text { Chlorophyceae } \\
\text { Coelastrum microporus } \\
\text { Scenedesums quadricauda } \\
\text { Coelastrum proboscis } \\
\text { Closterium venus } \\
\text { Chlamydomonas sp } \\
\text { Closterium macilenlum } \\
\text { Closterium lunnla } \\
\text { Closterium sp } \\
\text { Pendilastium tetras }\end{array}$ \\
\hline $\begin{array}{l}\text { Class } \\
\text { Family }\end{array}$ & $\begin{array}{l}\text { Cyanophyta } \\
\text { Cyanoplyceae } \\
\text { Oscillatoria princes } \\
\text { Spirulina major } \\
\text { Glococapsa minima } \\
\text { Spirulina princes }\end{array}$ \\
\hline $\begin{array}{l}\text { Class } \\
\text { Family }\end{array}$ & $\begin{array}{l}\text { Bacillariophyta } \\
\text { Bacillariophyceae } \\
\text { Cosinodiscus lacustro } \\
\text { Cyclotella striata } \\
\text { Diatoma sp } \\
\text { Synedra ulna } \\
\text { Navicula pusilla } \\
\text { Gomphonema angustatum } \\
\text { Nitzschta paradoxa }\end{array}$ \\
\hline
\end{tabular}


Table 2: Zooplankton collected from ponds at the African Regional Aquaculture Centre (ARAC), Aluu, Port Harcourt

\begin{tabular}{|ll|}
\hline Class & Protozoa \\
& Protozoae \\
& Arcella arenaria \\
& Difflugia constriata \\
& Centropipeis aculeate \\
& Arcella costata \\
& Arcella vulgaris \\
\hline Class & Rotifer \\
Family & Rotiferae \\
& Branchionus angularia \\
& Lepadella patella \\
& Brachiorus calyceflores \\
Class & Brachionus sp \\
Family & Copepoda \\
& Copepodae \\
& Copepoda sp \\
& Paracyclops fimbriatus \\
Class & Cyclops vicinis \\
Family & Onchocamptus mohamned \\
& Cladocera \\
& Cladocerae \\
& Moina dubia \\
& Spirostomum sp \\
& Prorodon ovum \\
& Podo polyphanoides \\
\hline
\end{tabular}

The results values obtained showed that temperature, depth, DO and transparency had the highest mean value of $\left(28.8^{0} \mathrm{C}\right),(57.5 \mathrm{~cm}), 4.9 \mathrm{mg} / \mathrm{l}$ and 42 ; while BOD has the lowest mean value of $1.4 \mathrm{mg} / \mathrm{l}$.

Table 3: The level of BOD, DO, temperature, depth $(\mathrm{cm})$ and transparency

\begin{tabular}{llllll}
\hline & Days & & & & \\
\cline { 2 - 5 } Parameters & $\mathbf{1}$ & $\mathbf{2}$ & $\mathbf{3}$ & $\mathbf{4}$ & Mean \\
\hline BOD $(\mathrm{mg} / \mathrm{l})$ & 1.0 & 0.95 & 2.0 & 1.7 & 1.4 \\
DO $(\mathrm{mg} / \mathrm{l})$ & 6.2 & 5.3 & 3.1 & 5.3 & 4.9 \\
Temp $(0 \mathrm{C})$ & 29.5 & 28.5 & 28.6 & 28.7 & 28.8 \\
Depth $(\mathrm{cm})$ & 50 & 50 & 60 & 70 & 57.5 \\
Transparency & - & - & 36 & 48 & 42 \\
\hline
\end{tabular}

The class cladocera species of Morina dubia, Spirostomum sp, Prorodon ovum, Podo polyphanoides, which in terms of relative abundance of individual populations accounted for $18.1 \%$ of all the organisms. Copepod was the next prominent constituting $16.7 \%$ of over all abundance. The remaining percentage was shared by Rotifera, Chlorophyta, Protozoa, Bacillariophyta, Euglenophyta and Cyanophyta. Cyanophyta had the least abundance $1.6 \%$ for plankton organisms.

Table 4: Percentage composition of families and species in each class of plankton in both ponds

\begin{tabular}{llll}
\hline Class & $\begin{array}{l}\text { Total no. } \\
\text { of Families }\end{array}$ & $\begin{array}{l}\text { Total no. } \\
\text { of Species }\end{array}$ & $\begin{array}{l}\text { Percentage species } \\
\text { Composition }\end{array}$ \\
\hline Euglenophyta & 1 & 8 & 17.7 \\
Chlorophyta & 1 & 9 & 20.0 \\
Cyanophyta & 1 & 4 & 8.8 \\
Bacillariophyta & 1 & 7 & 15.5 \\
Protozoa & 1 & 4 & 11.1 \\
Rotifer & 1 & 4 & 8.8 \\
Copepoda & 1 & 4 & 8.8 \\
Cladocera & 1 & 4 & 8.8 \\
Total & $\mathbf{8}$ & $\mathbf{4 5}$ & $\mathbf{9 9 . 5}$ \\
\hline
\end{tabular}




\begin{tabular}{llll}
\hline & Table 5: Percentage abundance of each class of plankton organisms \\
\hline Class & $\begin{array}{l}\text { Total no. } \\
\text { of individuals }\end{array}$ & Mean total no. of individual & $\begin{array}{l}\text { Percentage } \\
\text { abundance }\end{array}$ \\
\hline Euglenophyta & 221 & 28 & 10.0 \\
Chlorophyta & 288 & 23 & 13.0 \\
Cyanophyta & 110 & 28 & 5.0 \\
Bacillariophyta & 245 & 35 & 11.1 \\
Protozoa & 268 & 54 & 12.1 \\
Rotifer & 308 & 77 & 14.0 \\
Copepoda & 371 & 93 & 16.7 \\
Cladocera & 400 & 100 & 18.1 \\
Total & $\mathbf{2 2 1 1}$ & $\mathbf{4 4 7}$ & $\mathbf{1 0 0}$ \\
\hline
\end{tabular}

\section{DISCUSSION AND CONCLUSION}

The low diversity of plankton recorded in this study is not unusual in tropical water for instance, in lake George, Uganda, the plankton was poor in species (Burgis et al, 1993; Darlington, 1976). However, the significantly lower diversity of cyanophyta may be due to the fact that rainy reason was partly attributed to the indirect effect of the rains on the surface water and the substrate. It was pointed out that during this period, the surface water and substrate was unstable being either washed off or submerged, especially during the flood season. Cognetti (1982), observed that certain euryhaline species may be absent in one biotipe and instead be present in another and may occur in large numbers in most ecological unpredictable zones. Vermerji (1978) categorized species and referred to opportunists with high reproductive rates, short life span, high dispensability, reduced long term competitive abilities and which occupy ephemeral or disturbed habitats.

The fact that BOD and temperature significantly affected the distribution of some plankton organisms along the ponds under scores the danger posed by fertilizer with organic and inorganic manure. Odokuma and Okpokwasili (1996) observed that high and low BOD fluctuations between seasons might be attributed to additional organic matter and soil erosion caused by increased rainfall during the rainy season.

This study reveals that zooplankton classes had highest number of individuals than the phytoplankton classes. Hunnan (1981), also observed that organic fertilizers are especially efficient in increasing the abundance of zooplankton. He further stated that they are detritus which stimulate the heterotrophic food chain producing more bacteria and zooplankton.

Information gained from this study indicates that the plankton of the two ponds are highly diverse and that, BOD, DO and temperature influence their composition and distribution in the pond.

In conclusion, species diversity is relatively poor and showed significant variation in abundance. The differences observed in the distribution of species indicated the dependency on prevailing environmental conditions and the ability of each organisms to exploit and tolerate varied biotipe. Studies of this nature are important in understanding the composition of plankton populations especially in the lower part of Niger Delta where published information on the study is scanty.

\section{REFERENCES}

American Public Health Association, APHA., 1998. Standard Methods for Examination of Water and Waste Water $20^{\text {th }}$ edition, Washington, DC, 2-4.

Barnes, R. D., 1980. Invertebrate Zoology $4^{\text {th }}$ ed. W.B. Saunders London, 1089.

Burgis, M. J., Darlington, J. P. E. C., Dunn, I. G., Ganf, F. G., Gwahaba, J. J and McGowan, L. M., 1993. The Biomass and Distribution of Organism in Lake George, Uganda. Proc. Roy. Soc. Lond. 13, 184:95-112.

Cognetti, G., 1982. Adaptative Strategy of Brackish Water Fauna in Pure and Polluted Waters. Mar Poll Bull 13, (7): 247-250.

Darlington, J. P. E. C., 1976. Temporal and Spatial Variation in the Benthic Invertebrates Fauna of Lake George, Uganda J. 2001 London, 180, 95112.

Eze, E. N., 2001. Comparative Studies of the Flood Plains and Major Rivers Odioko-Ekpeye, Rivers State, Nigeria. M.Sc. Thesis University of Port Harcourt, 98.

Hart, A. I., 1994. The Ecology of the Communities of Benthic Macro-fauna in the Mangrove Swamp of Port Harcourt Area of the Niger Delta. Ph.D Thesis, University of Port Harcourt, Rivers State.

Hunnan, C. A., 1981. Polychaeta Larvae Settlement Correspondence of Patterns in Suspended. Jar Collector and in the Adjacent Natural Habital in Montuy, Bay, California, Limnol Oceangr. 26, 159-171.

Kasza, $\mathrm{H}$ and Edward, K., 1993. Directional Changes in Communities of Botton Macrofauna against the Background of Changing Hydro-chemical Parameters of the Rivers, Vistula, Hydrobiology Journal, 43-230.

Menzel, U and Rhyther, E., 1980. Animal Life in Fresh Water, A Guide to Fresh Water Invertebrates. Chapman and Hall, London, 308. 
Odokuma, L. O and Okpokwasili, G. C., 1996. Seasonal Influence of the Organic Pollution Monitoring of New Calabar Rivers Nigeria. Environ. Mon and Assess, 45-43-56.

Raymond, E. G., 1983. Plankton and Productivity in the Oceans $2^{\text {nd }}$ ed. Vol. 1, Perganmon Press, 502.

Southerland, S. P., 1980. Dynamics of the Epibenthic Community on Roots of the Mangrove Rhizophora Mangle at Balana Debuche, Vanazuela Mar boil 58, 75-84.

Swingle, H. S., 1985. Experiment on Pond Fertilization. Bull Ala. Agric. Exp. Station (264): 34.

Swingle, H. S and Smith, E. V., 1999. The Relationship between Plankton Production and Fish Production in Ponds. Trans Ameri Fish Soc. (68): 309-315.

Vermerji, G. J., 1978. Biogeography and Adaptation Patterns of Marine Life. Harvard University Press Cambridge Mass Achusetts U.S.A. 